\title{
Award-Winning Faculty Online Teaching Practices: Elements of Award-Winning Courses
}

\author{
Swapna Kumar \\ University of Florida \\ Florence Martin and Kiran Budhrani \\ University of North Carolina Charlotte \\ Albert Ritzhaupt \\ University of Florida
}

\begin{abstract}
The purpose of this study was to explore award-winning instructors' insights on elements of their course design that were award-winning and the differences between expert and novice online instructors. Interviews were conducted with eight award-winning online faculty members from across the United States who had received online teaching awards from one of three professional associations. The five main areas that emerged from the data analysis were (a) authentic and relevant course materials that connect to practice, (b) the use of multimedia resources, (c) student creation of digital content individually and collaboratively, (d) students' reflection on learning, and (e) the instructor's explanation of the purpose of activities, technologies, and assessments in the online course. Additionally, award-winning faculty emphasized the importance of using data and evaluation practices and reflecting on course offerings in the development of an excellent online course. Award-wining faculty described expert online instructors as being experienced and comfortable in the online environment, using a wide range of strategies, being willing to learn, using data and analytics, and engaging in continuous improvement. The findings add to the literature on best practices and what constitutes excellence in online courses.
\end{abstract}

Keywords: award-winning online faculty, online course design, online teaching practices, qualitative research

Kumar, S., Martin, F., Budhrani, K., \& Ritzhaupt, A. (2019). Award-winning faculty online teaching practices: Elements of award-winning courses. Online Learning, 23(4), 160-180. doi:10.24059/olj.v23i4.2077

\section{Award-Winning Faculty Online Teaching Practices: Elements of Award-Winning Courses}

Over more than a decade, online education in the United States has experienced steady growth in the number of courses and programs offered at higher education institutions. Seaman, Allen, and Seaman (2018) report that approximately $31.6 \%$ of all students took an online course in fall 2016, an increase of 5.6\% from fall 2015. As institutions increase their online offerings, they seek to continuously improve the design, implementation, and assessment of online courses 
and programs. Simultaneously, guidelines and frameworks have been developed at the local, state, and national levels to ensure the quality of online courses (Baldwin \& Trespalacios, 2017; Baldwin, Ching, \& Tsu, 2018; Brown, Lewis, \& Toussaint, 2018), and awards for excellence in online course design and teaching have been instituted by established professional organizations. This paper focuses on the insights of experienced online faculty who have won such awards for exemplary online course design and teaching to identify what course elements contributed to winning an award, and to understand what distinguishes expert online instructors from novice online instructors.

Researchers have previously researched the practices of award-winning faculty in higher education (Dunkin \& Precians, 1992; Kember \& McNaught, 2007; Morris \& Usher, 2011) and, more recently, in online education (Bailey, 2008; Martin, Ritzhaupt, Kumar, \& Budhrani, 2019) in order to understand their successful online teaching and learning practices. In this study, we focus on the award-winning elements of course design and the distinctions between expert and novice online instructors as perceived by award-winning online faculty. Studying the online course design and teaching practices of award-winning faculty can serve as a model for other faculty and instructional designers aiming for excellence in online education, and can be used in faculty development efforts and readiness efforts (Baran \& Correia, 2017; Gay, 2016). Further, awardwinning online faculty expertise can provide a source of valid guidelines, standards, and best practices to extend the current state of online teaching and learning research and practice.

\section{Review of Relevant Literature}

\section{Elements of Course Design}

Online courses are structurally complex to design and develop because they contain a wide range of course elements, such as digital resources (R), activities (A), supports (S), and evaluations (E), and a model for design that focuses on these elements has been termed the RASE learning design model (Churchill, King, \& Fox, 2013). Digital resources include the content, instructional materials, and tools that students use while working on activities. Activities are designed for students to engage in inquiry, problem-solving, projects, or collaborative work for achieving learning outcomes. Supports are in place to ensure students know where to seek help and who to seek help from. Evaluation is conducted to inform both students and faculty about progress toward expected learning outcomes. The RASE model was developed to assist faculty in designing for student-centered, technology-integrated learning environments. For such learning environments to be effective, all four elements are required, but the central focus must be on the design of learning activities rather than on the digital resources; resources should become mediating tools for faculty as they facilitate learning, provide support for learners, and evaluate learning outcomes (Churchill, 2017a, 2017b; Churchill, King, \& Fox, 2013). Each element is further elaborated in the succeeding sections.

Digital resources (the $R$ in RASE) for learning are best described as "technology-based multi-media content specifically designed for education and training purposes" (Churchill, 2017b, p. 2). The visual and interactive capabilities of educational technology have progressed significantly with the development of video architecture, mobile technologies, and software tools. Digital resources, such as e-books, Web content, educational videos, animation, simulations, interactive multimedia, podcasts, and open educational resources have become more user-friendly, and easier to find, access, and create (Miller, \& CohenMiller, 2019; Ross, Volz, Lancaster, \& 
Divan, 2018). These offer opportunities to instructors and students to become curators of resources for a specific learning goal or topic (Correia \& Jaramillo, 2016; Espiritu \& Budhrani, 2019; Sharp \& Hamil, 2018).

Instructors need to be intentional in creating and selecting digital resources according to their learning purpose, such as information display, presentation, practice, conceptual representation, or data display (Churchill, 2017b). Instructors also need to evaluate the instructional effectiveness and value of learning resources, ensuring those selected align to the given context, curriculum, and outcomes, and instructors must adjust materials based on credibility, clarity, validity, reliability, accuracy, currency, accessibility, usability, and quality of course resources (Varvel, 2007). Advanced interactive video assessment tools help shift passive learning into active knowledge construction, where students interact with video lectures through embedded question checks, and instructors track data on students' viewing and responses to questions (Chen \& Wang, 2016; Giannakos, Krogstie, \& Aalberg, 2016).

Learning activities (the $A$ in RASE) need to be intentionally created or selected by instructors to provide experiences and opportunities for learners to construct and use knowledge from digital resources. Koohang, Paliszkiewicz, Klein, and Nord (2016) suggest that learning activities must be intentionally designed for deep knowledge construction and critical thinking in online courses, and such is only achievable with appropriate scaffolding of activities. Active learning methods and strategies, such as problem-based learning, cooperative learning, collaborative learning, and peer learning, can support individual or group activities online (Bishop \& Verleger, 2013; Cundell \& Sheepy, 2018). However, activity design cannot be static; instructors must be able to frequently modify activity instructions and tasks according to the number of persons involved in the learning activity, whether a whole class, a group, or an individual (Espiritu \& Budhrani, 2019).

Academic and nonacademic support (the $S$ in $R A S E$ ) are essential for online learning students at the institutional, program, and course levels both to assure retention and avoid the feelings of isolation that can occur in online learning spaces (Mentzer, Black, \& Spohn, 2015; Simpson, 2018). Supports for online learners are manifested in a multitude of ways following the traditional modes of interaction: student-to-student, student-to-content, and student-to-instructor (Moore, 1993). At the course level, online instructors should attempt to anticipate student needs and expectations as unforeseen circumstances emerge in the online learning space; such could be grasped with interactive communication tools, such as forums, email, chat, social media, or other synchronous or asynchronous tools (Churchill, 2017a).

Evaluation (the $E$ in $R A S E$ ) includes explicit evidence in the form of student feedback and evaluations, observations of classroom engagement/participation, and performance on assessment tasks, and it can personally validate and inform faculty design decisions (Bennett, Agostinho, \& Lockyer, 2015; Markauskaite \& Goodyear, 2014). Some faculty also utilize formal questionnaires or surveys to gather more accurate knowledge or feedback from students focused on problems identified during teaching. Finally, instructors may use research-informed or evidence-based teaching to analyze, explain, and reflect on their teaching, and ultimately, to help them make better informed course-design decisions (Bennett et al., 2015; Masterman, 2013).

Instructors are strongly guided by what they know about course design or teaching, especially by what they have experienced in the past. Their content expertise, design knowledge, prior experience, personal beliefs, and contextual constraints influence their course design. At the 
same time, they consider learner characteristics, institutional and departmental policies, available resources and materials, and curricular requirements. In addition, they design activities and lessons with considerations of time, rigor, student readiness, and distribution of workload (Bennett, Lockyer, \& Agostinho, 2018; Markauskaite \& Goodyear, 2014; Nguyen \& Bower, 2018). Different decisions on course elements take time to assess depending on what needs to be created from scratch, modified, or reused from a previous iteration of the course.

Clarity and transparency of course design. In practice, researchers have found that students have increased academic confidence when instructors are transparent about the purpose of the course content and activities, the tasks that students have to complete (i.e., what to do and how to do it), and the criteria for success (i.e., what excellence looks like, criteria to help students to self-evaluate; Fisher, Kouyoumdjian, Roy, Talavera-Bustillos, \& Willard, 2016; Musselman, Lock, Long, Loughran, \& Saclolo, 2016). Examples of increased transparency include clarifying class goals, roles, and assignments for both students and instructors; providing detailed assignment instructions and rubrics for grading; including instructions explicitly linking the course learning outcomes; and providing samples of exemplary work for projects (Fisher et al., 2016; Musselman et al., 2016). Ralston-Berg, Buckenmeyer, Barczyk, and Hixon (2015) found that students placed great importance on the inclusion of clear instructions for getting started in a course and consistent and logical navigation; students also greatly value clearly articulated assessments and policies for grading.

It is important for instructors to make their intentions and decisions for each course element visible to students, explaining the learning rationale behind various teaching and learning approaches so that students understand why they are being asked to do something (Hattie, 2012). When students know the purpose behind activities, they are more likely to take an active role and greater responsibility in their learning. Transparency and visibility of relationships between online course elements are also reflected in several standards of the Quality Matters Rubric (Quality Matters, 2019).

Expert and novice online instructors. Prior research on expert and novice online faculty has mainly focused on studying expert, exemplary, or experienced instructors and their teaching practices (Hixon, Barczyk, Ralston-Berg, \& Buckenmeyer, 2016). Lewis and Abdul-Hamid (2006) studied exemplary online faculty's teaching to find that they were organized, fostered interaction, provided timely feedback, facilitated learning, and maintained student enthusiasm. Exemplary online faculty studied by Edwards et al. (2011) were classified as challengers, affirmers, and influencers. Baran, Correia, and Thompson (2017) reported that exemplary faculty not only knew their content and their students but also knew how to design their online course, guide student learning, enhance student-teacher relationships, and maintain teacher presence. Additionally, exemplary online faculty formatively evaluated their online courses in order to make changes during the course. Watson, Koehler, Ertmer, Kim, and Rico (2018) found that expert instructors selected facilitation choices with course goals in mind and modeled the case analysis process, improving students' problem-solving. Further, experienced instructors considered the four characteristics of expert instructors to be (a) significant length and breadth of their online teaching experience; (b) personal characteristics such as curiosity, tenacity, and organization, and professional skills such as technical skills; (c) instructional design experience; and (d) effective teaching styles (McGree, Windes, \& Torres, 2017). Martin, Budhrani, Kumar, and Ritzhaupt (2019) found that expert online faculty assume the roles of the designer, manager, subject-matter expert, facilitator, and mentor in online courses, while Bailey and Card (2009) discussed eight 
areas related to experienced online instructors - fostering relationships, engagement, timeliness, communication, organization, technology, flexibility, and high expectations.

\section{Research Questions}

The purpose of this study was to identify what constitutes excellence in online course design and what distinguishes expert online instructors. Thus, the following were our research questions:

1. What elements of their online courses did award-winning faculty perceive as awardwinning?

2. What do award-winning online faculty perceive as the distinction between an expert and novice online instructor?

\section{Method}

A general qualitative approach was used in this study "to understand how people make sense of their experiences" (Merriam \& Tisdell, 2016, p. 24). In order to sample award-winning faculty who could participate in this study, three awards were identified:

- The Crystal Online Teaching Award from the Association for Educational Communications and Technology (AECT). This award uses eight criteria to recognize innovative and outstanding multimedia-based distance learning courses. Innovation in course design, evidence of effectiveness, and a basis in scholarly literature are three of the criteria (AECT, 2018). AECT provides three crystal awards each year in the order of first place, second place, and third place.

- The Excellence and Innovation in Online Teaching Award from the Online Learning Consortium (OLC), for which applicants have to provide evidence of the effectiveness in achieving desired learning outcomes. This award requires that applicants should have designed and taught one or more online courses with well-designed course materials and instructional strategies, and demonstrated a rapport with learners (OLC, 2018). OLC provides one award each year.

- The Best Practices Awards for Excellence in Distance Learning Teaching from the United States Distance Learning Association that recognizes teaching that demonstrates extraordinary achievements on the part of an outstanding individual or team of individuals (USDLA, 2018). USDLA confers only one award each year.

Fifteen faculty who had won one of the three awards in the past 10 years (since 2015) were contacted by email. Eight of the 15 agreed to participate, of which six were female and two were male. Five had won OLC's Excellence and Innovation in Online Teaching, two had won the AECT's Crystal Award, and one had won the USDLA's Best Practice Award for Excellence in Distance Learning Teaching. Their teaching experience at a distance or online ranged from 5-42 years, and they had used many different learning management systems (LMS) in their blended and online courses (Table 1).

For common understanding, we adapted the OLC's recent definitions for blended and online courses (Sener, 2015). A blended (also called hybrid) online course is where "most course activity is done online, but there are some required face-to-face instructional activities" (Sener, 
2015, para. 12). An online course is where all course activity is done online; there are no required face-to-face sessions within the course and no requirements for on-campus activity (Sener, 2015, para. 14).

Table 1

Demographics of Eight Award-Winning Faculty

\begin{tabular}{|c|c|c|c|c|c|c|}
\hline ID & Gender & Award & $\begin{array}{l}\text { Years } \\
\text { teaching } \\
\text { in H.E. }\end{array}$ & $\begin{array}{l}\text { Years } \\
\text { teaching } \\
\text { online }\end{array}$ & $\begin{array}{l}\text { LMS } \\
\text { experience }\end{array}$ & Modality \\
\hline 1 & $\mathrm{~F}$ & $\begin{array}{l}\text { Excellence in Online } \\
\text { Teaching, OLC Award }\end{array}$ & 20 & 15 & $\begin{array}{l}\text { Genzibar, } \\
\text { WebCT, } \\
\text { Desire2Lear } \\
\text { n, Canvas, } \\
\text { Blackboard }\end{array}$ & $\begin{array}{l}\text { Blend of } \\
\text { asynchronous } \\
\text { and } \\
\text { synchronous }\end{array}$ \\
\hline 2 & $\mathrm{~F}$ & $\begin{array}{l}\text { Excellence in Online } \\
\text { Teaching, OLC Award }\end{array}$ & 30 & 6 & Blackboard & Asynchronous \\
\hline 3 & $\mathrm{~F}$ & $\begin{array}{l}\text { Excellence in Online } \\
\text { Teaching, OLC Award }\end{array}$ & 14 & 12 & $\begin{array}{l}\text { Blackboard, } \\
\text { Moodle, } \\
\text { Canvas }\end{array}$ & Asynchronous \\
\hline 4 & $\mathrm{~F}$ & Crystal Award, AECT & 23 & 5 & $\begin{array}{l}\text { WebCT, } \\
\text { Blackboard, } \\
\text { WordPress, } \\
\text { WikiSpaces }\end{array}$ & $\begin{array}{l}\text { Mostly } \\
\text { asynchronous } \\
\text { with some } \\
\text { synchronous }\end{array}$ \\
\hline 5 & $\mathrm{~F}$ & Crystal Award, AECT & 15 & 5 & $\begin{array}{l}\text { None } \\
\text { identified }\end{array}$ & $\begin{array}{l}\text { Blend of } \\
\text { asynchronous } \\
\text { and } \\
\text { synchronous }\end{array}$ \\
\hline 6 & M & $\begin{array}{l}\text { Gold, Online } \\
\text { Technology } \sim \text { Higher } \\
\text { Education, Best } \\
\text { Practices Awards for } \\
\text { Excellence in Distance } \\
\text { Learning Teaching }\end{array}$ & 31 & 9 & Blackboard & $\begin{array}{l}\text { Mostly } \\
\text { asynchronous } \\
\text { with some } \\
\text { synchronous }\end{array}$ \\
\hline 7 & M & $\begin{array}{l}\text { Excellence in Online } \\
\text { Teaching, OLC Award }\end{array}$ & 44 & 42 & Blackboard & Asynchronous \\
\hline 8 & $\mathrm{~F}$ & $\begin{array}{l}\text { Excellence in Online } \\
\text { Teaching, OLC Award }\end{array}$ & 18 & 15 & $\begin{array}{l}\text { CAD, } \\
\text { Blackboard, } \\
\text { InterLearn, } \\
\text { Moodle }\end{array}$ & Asynchronous \\
\hline
\end{tabular}

Adapted from "Award-Winning Faculty Online Teaching Practices: Roles and Competencies," by F. Martin, K. Budhrani, S. Kumar, \& A. Ritzhaupt, 2019, Online Learning, 23(1), pp. 188-189. Copyright Online Learning Journal. Reproduced with permission. 


\section{Data Collection}

After an extensive literature review, a semistructured interview protocol was created that focused on course design, facilitation, and evaluation. Fourteen open-ended questions were crafted with a focus on content, clarity, and sequencing (Patton, 1990). Care was taken to not use technical terms familiar to faculty in instructional design or educational technology but unfamiliar to faculty from other disciplines. The questions were reviewed by the research team consisting of four members with online teaching experience. This paper reports on course design and evaluationnamely, the questions in the interview guide that focused on what award-winning faculty perceived as design elements of their courses that were "award-winning," how they engaged in the evaluation of their courses, and what they perceived as the distinctions between novice and expert online instructors.

Web-based interviews were conducted with all eight online instructors using NetMeeting (Web-conferencing software) and digitally recorded with participant permission within the software. Each interview took about 30 minutes. The interview questions were displayed on the screen to assist the interviewees in staying focused and answering the questions during the interview. In addition to the open-ended interview questions from the semistructured interview protocol, several probes were used during the conversations to further clarify participants' statements.

\section{Data Analysis}

Following the transcription of the interviews, each interview was read by two researchers who checked that all the questions from the interview protocol had been asked. Next, they compiled the data from the eight interviews according to responses to each research question. Two members of the research team first coded all eight responses to one question using elemental coding methods. For credibility and dependability, they then discussed the descriptive, in vivo, and process codes (Saldana, 2015) in detail. The two researchers then coded the data for the remaining questions, discussed and reached agreement, and implemented axial coding. Categories were created by comparing and collapsing codes and then reviewing categories across questions before finalizing themes. Care was taken to retain details and examples from the raw data that represented the codes and that would be useful to online faculty or course designers aiming to create excellent online courses.

\section{Results}

The faculty in this study were asked to describe their award-winning course and what they felt made it award winning. The five main areas (Table 2) that emerged across the eight interviews were (a) authentic and relevant course materials that connect to practice; (b) the use of multimedia resources; (c) student creation of digital content individually and collaboratively; (d) students' reflection on learning; and (e) the instructor's explanation of the purpose of activities, technologies, and assessments in the online course. These "award-winning" elements are discussed in the first section of the results. Additionally, a sixth area emerged, discussed in the second section, that did not pertain to an element of the online course itself but to how the instructor used data and engaged in continuous improvement in the course. Finally, we present award-winning faculty's insights into what distinguishes an expert from a novice online instructor. 
Table 2

The Five “Award-Winning” Elements in the Eight Interviews

\begin{tabular}{|llllll|}
\hline Faculty & $\begin{array}{l}\text { Authentic and } \\
\text { relevant course } \\
\text { materials that } \\
\text { connect to } \\
\text { practice }\end{array}$ & $\begin{array}{l}\text { The use of } \\
\text { multimedia } \\
\text { resources }\end{array}$ & $\begin{array}{l}\text { Student creation } \\
\text { of digital } \\
\text { content } \\
\text { individually and } \\
\text { collaboratively }\end{array}$ & $\begin{array}{l}\text { Student } \\
\text { reflection on } \\
\text { learning }\end{array}$ & $\begin{array}{l}\text { Instructor's } \\
\text { explanation } \\
\text { of purpose }\end{array}$ \\
\hline 1 & X & X & X & X & \\
2 & $\mathrm{X}$ & $\mathrm{X}$ & $\mathrm{X}$ & $\mathrm{X}$ & $\mathrm{X}$ \\
3 & $\mathrm{X}$ & $\mathrm{X}$ & $\mathrm{X}$ & $\mathrm{X}$ & $\mathrm{X}$ \\
4 & $\mathrm{X}$ & $\mathrm{X}$ & $\mathrm{X}$ & $\mathrm{X}$ \\
5 & $\mathrm{X}$ & $\mathrm{X}$ & $\mathrm{X}$ & $\mathrm{X}$ & $\mathrm{X}$ \\
6 & $\mathrm{X}$ & $\mathrm{X}$ & $\mathrm{X}$ & $\mathrm{X}$ & \\
7 & $\mathrm{X}$ & $\mathrm{X}$ & $\mathrm{X}$ & $\mathrm{X}$ & $\mathrm{X}$ \\
\hline 8 & $\mathrm{X}$ & $\mathrm{X}$ & $\mathrm{X}$ & $\mathrm{X}$ & \\
\hline
\end{tabular}

Authentic and relevant course materials that connect to practice. All the faculty interviewed included innovative course materials that were authentic and that would be relevant to students' interests and professional contexts. One online instructor emphasized the value of such materials to experiential learning online. This instructor highlighted the importance of, "pulling in real-world problems, up to-date real-world problems into the classroom, applying new knowledge that you're acquiring every single week to that experiential learning and illustrating to yourself, your teacher, your stakeholders, your profession that you are capable of going out as problem solvers." Examples of such resources were

- snippets of recordings from a radio show aired weekly that was related to course topics, and which students were required to discuss in an online forum;

- videos from courtrooms and recorded interviews with prosecutors about specific aspects of legal cases in order to provide students with insight into the reality for their future profession, illustrate how things really work, and have them engage with "real" problems; and

- recorded podcasts with experts on the course topics to model their thinking and provide authentic material to the students.

A common theme that emerged among the faculty was the relevance of the materials and activities to students' future professions. An award-winning instructor explained,

They were preparing to be science, social studies, and math teachers. ... So I did a great deal of just general knowledge...like what is a math teacher going to be facing in a high school class? ... I developed assignments, which I thought would be useful for those classes in the field.

Another online instructor believed in the value of providing students with the larger picture by using materials on different aspects of a case study. Learning activities described by this particular online instructor included student research for materials on the case study, following which this instructor provided authentic materials about real events and interviews with those related to the case study that were discussed by students. 
Use of multimedia resources. The authentic and relevant materials that faculty included in their courses took the form of various media. Faculty used videos or songs available on YouTube and authentic interviews, podcasts, radio broadcasts, news articles, and media to provide students with real-world content. In addition to finding existing materials, they also created multimedia materials specifically for their courses. For example, they recorded screencasts, interviews with experts and professionals in the field, lectures, and podcasts. They also created multimedia presentations using various technologies. One instructor created interactive flowcharts that students could control and that would illustrate changes within a system. One online instructor used various types of technologies to address students' different learning styles, and another online instructor highlighted the value of using a variety of learning technologies, stating, "students have access to a tremendous amount of resources, articles, up-to-date best practices. But it's important especially in online learning that you have a variety of learning tools. You cannot simply just have text." One online instructor reflected on how much students appreciated such materials, stating,

I'd been using VoiceThread, I've seen so much growth and community in the course and the ability for students to hear me and see me was like they were giving me this incredible feedback. ... Then I had also started recording lectures as enhanced podcasts. ... So those two things at that time were very, very new and again I was getting overwhelming feedback from students who'd go "this is so amazing!"

Student creation of digital content individually and collaboratively. In addition to integrating multimedia resources in their online courses, award-winning faculty required students to create different types of digital content and interact with each other using both synchronous and asynchronous technologies. Some online instructors provided students with options and allowed them to choose the technologies to create their digital content, whereas others required specific technologies. They reasoned that such activities were important for students to relate the course content to their own lives and contexts, and to demonstrate their learning.

Faculty provided several examples of such activities and how they contributed to student learning and to their winning of an award, as follows:

- Students created digital stories using technologies such as Photo Story or PowerPoint after choosing a topic of their choice that related to their subject-matter expertise and that connected course content to their lives. The online instructor reflected that, "the digital storytelling project also won some awards. I think because it was engaging, and because it was related to their lives."

- Students were required to read critical articles or text and create short (2-3 minute) presentations as podcasts. The award-winning instructor who used this strategy stated, "I think the review found my use of podcasts as a way to engage the students in an assignment as a unique thing."

- Students' major assignment was an electronic study guide that they could use with their future students, which consisted of a Web page with different tabs, and which distilled everything that they were learning in the online course. The online instructor considered it the award-winning aspect of the course.

- Students interviewed experts in the field and created audiovisual presentations that synthesized the interviews and course content. 
- Students worked together with peers at another university in real-time sessions (using Zoom software) to gather information and create collaborative projects that they presented at the end of the course. The projects focused on the geographical regions of the two sets of students, helping them compare and discuss course topics in their contexts.

- Students created a digital presentation in which they applied and connected theories in the course to the responsibilities of a professional in their field.

- Students used Twitter to discuss course topics. They were required to tweet in three different ways each week about the content of the course that week. The online instructor described the tweets as "an informational tweet," "an attitudinal tweet," and a tweet with a link to a current resource. The course used a hashtag that helped curate tweets and facilitate student dialogue. The online instructor believed that this pushed students "out of the pure academic environment out into the social media environment where things are a little rougher. [They] got to watch their opinions and be smarter about things but students enjoyed it for the most part."

- Students had an online debate about benefits and drawbacks [of a course topic]. The online instructor explained, "It's experiential, it's holistic, connecting all the different parts. It provides engagement for the students."

Students' reflection on learning. In the online courses described by faculty in this study, student learning was assessed formatively and summatively using different activities, and students were also expected to demonstrate reflection on their learning. Faculty used a combination of weekly quizzes, discussion forums, student-created podcasts, blogs, VoiceThreads, presentations, artifacts (described in the previous section), self-assessments, peer assessments, position papers, final papers, and exams. All the online instructors used assignments in which students demonstrated what they had learned using either quizzes or digital technologies and then reflected on what they learned. For example, one award-winning online instructor created a screencast explaining answers in a quiz. Another award-winning instructor had students return to their answers in a quiz to reflect on their learning together, and a third had students reflect on their discussion posts (e.g., "how often did they post, what did they think of their posts, what did they learn?"). Another online instructor used an assessment rubric that students used to assess themselves and their interactions with their peers.

Online instructors described these activities as helping students understand their educational journey, understand "their own value of learning and how far that they have come," and help them "assess their learning and helping me understand the degree to which they have achieved learning outcomes in the class." A common theme that emerged across the interviews was the use of assessments that helped students assess their own learning and reflect on it. This also helped the online instructors identify individual and collective gaps in knowledge.

Explanation of purpose. The faculty in the study asserted that it was important to explain to students the purpose of the modules and content, the purpose of assessments, and the purpose of the technology that they used in their activities or assessments. At the beginning of each module within the online course, one instructor emphasized the importance of providing an explanation of what students were learning and why, stating, "It introduces them to the work, why it's included, what are we going to do with it." Likewise, an instructor explained to students how the course topics were connected within the field of study and related to the field and profession. Whenever technology was used within the course, one instructor found it important to communicate to 
students "why that technology makes sense for the learner." This was also the case with activities and assessments, where one instructor highlighted the value of communicating reasons for the assessments:

The students need to understand what it is that they are reaching for and how we are going to get through, I provide a pathway for them. I explain why we are assessing certain types of learning, why are you taking this quiz? Why are you engaging in this debate, what is it that you should know as you go through this pathway and come out the other side.

\section{Award-Winning Faculty's Use of Data in Online Courses}

An important element in the development of an award-winning course was the way in which instructors had collected data on the course or engaged with existing evaluation data, reflected on how to improve the course, and made improvements. The eight award-winning instructors described various ways in which they and their institutions engaged in course evaluation for continuous improvement and quality management of a course. They used (a) student evaluations and surveys, (b) student achievement outcomes and analytics, (c) peer reviews and external reviews, and (d) reflection and course improvement.

Student evaluations and surveys. In addition to institutional student evaluations of online courses that focused on both course design and facilitation, online instructors created midsemester and end-of-semester surveys that they used to gather student feedback on various aspects of their online courses (e.g., to identify what was working or not). Online instructors stated that student evaluations often asked students about their perceptions (e.g., of the online instructor or whether the learning objectives of a course had been met) and measured student satisfaction. One online instructor reflected that over multiple offerings of a course, student surveys as well as evaluations provided feedback, "data," and "themes" that instructors could "build upon" during subsequent terms.

Student outcome achievements and analytics. Accreditation and larger program outcomes were a major course-quality consideration for four online instructors who perceived their online courses as part of program curricula with program goals. They described different ways in which student data, student feedback, and student work were used to assess whether student learning outcomes were being met in online courses or online programs. Two online instructors described the extensive use of rubrics to assess specific student-learning outcomes that were important for online courses or programs to be accredited or even just to maintain course quality at an institutional level. One online instructor explained,

We work pretty closely with our institutional office. ... They've utilized best practices and rubrics, and they give me ... a kind of a bulleted list of their reading on what's happening within a particular course and based upon that, I will go back into the course and take a look at what we're doing and how we're doing it. It's actually been beneficial to me.

Two other online instructors described the analysis of data collected from learning management systems and assessments for comparison across semesters, across sections, or for relating to the national average. They stated that course quality and the meeting of learning objectives or "intended outcomes" at a program level were implemented at their institutions. One online instructor explained, "We do program assessment every year. ... We are basically 
evaluating ... are the students proficient in what we said they'd be proficient? We look at different assignments that were meant to speak to proficiencies, various outcomes."

Peer reviews and external reviews. Three online instructors described how peer reviews and external reviews were used to evaluate online courses at their institutions. One online instructor described the peer evaluation as follows: "The course owner, the course lead faculty will go in and observe the performance of the teaching faculty inside of the course in multiple ways. They fill out a rubric, they provide that feedback to the teaching faculty, and then we have a number of faculty development courses that we may recommend." Another online instructor described the use of an external review, where specific artifacts from courses were sent to third parties who are experts in the field to "evaluate those artifacts to determine if the students are indeed meeting the intended outcomes and at what level are they meeting those outcomes." This online instructor emphasized that unbiased input from external evaluators is "very useful" and it "pushed" him to make changes to courses.

Faculty reflection and course improvement. When online instructors discussed the different ways in which courses were evaluated, all of them emphasized that the final goal of that evaluation was online course improvement. Whether it was student evaluations, achievements, assessments, or peer/external reviews, they asserted that the value of these processes was course redesign, and improvements to alignment between objectives and outcomes. A theme that emerged was that award-winning faculty reflected on their online courses and used the results of evaluation processes to improve them. Three online instructors invested time in reviewing their online courses after they ran and assessed whether they were achieving what they had set out to do. One online instructor stated that he would review a major assignment every semester in the following manner:

I have ... notes saying here are the points that they [students] should take out of it and here's what they should have learned. And I use all the online arguments that they've presented as a being proof of did they get it or did they not get it. And then

I go back and figure out why half this class missed this important point.

\section{Distinction Between Novice and Expert Online Instructors}

The award-winning faculty were asked how expert instructors differ from novice instructors who teach online. They stated that expert online instructors "know what works" based on experimentation, experience, understanding how online teaching differs from face-to-face teaching, and their analysis of student learning. They possess a wide range of strategies and are willing to learn. Expert online instructors have taught online for a while, which gives them "some confidence in what works and in what doesn't work." One online instructor stated, "It's about the third time you teach it that you know what really works and doesn't work." Experts are able to identify problems and realize that they have to approach things differently if they don't work, because they are able to see "here's what's going on, here's what should be going on, and here's how we go from there." Online teaching experience, according to the online instructors, also leads to an expert no longer thinking about or being limited by the technology. One online instructor stated, "I think the expert instructor is one that would no longer feel boxed in by the LMS, by the technology such as this, and feels free to express and does so."

Novice instructors, according to one online instructor, are focused on getting their courses into the LMS and are overwhelmed by the time taken by an online course, whereas expert instructors are constantly monitoring and tweaking and evaluating because they are beyond the 
initial stages. Another online instructor reflected that although novice instructors have subjectmatter expertise,

it's the design that falls short. They don't know how to organize their materials or set up a design that makes sense to move students in a progression towards course work. I think novice instructors sometimes, in my experience, fall short on some of the needed repetition of information that you need to provide students to keep them on track in that format.

Expert instructors recognize clear course design, effective pedagogy, and the struggles of students, and they take an experimental approach to instruction. One online instructor stated,

You can't just take your material you've provided in class and put it online. The whole thing about being center stage, some people are when they lecture, that's completely out of the ballpark when you are teaching online. So, I think for me that's the greatest way they differ when you have someone new to online instruction.

Expert instructors also know how to adapt their materials to the online format, "what tools to use in which assignments, and what creates a good assignment." Furthermore, expert instructors are more likely to understand the need for "breadth versus depth" in an online course. The awardwinning online faculty elaborated that expert instructors choose their content carefully and choose their actual activities to focus on the ones that are really important and drop those that are not. Table 3 summarizes key characteristics of expert and novice online instructors.

Table 3

Expert and Novice Instructors

\begin{tabular}{|l|l|}
\hline \multicolumn{1}{|c|}{ Expert instructors } & \multicolumn{1}{c|}{ Novice instructors } \\
\hline - Know what works in the online format & - Focus on getting the course on the \\
- Possess a wide range of strategies & LMS \\
- Have confidence in online teaching & - Are overwhelmed with the time online \\
- Are able to identify problems & teaching takes \\
- Are not limited by technology & - Need support on course design \\
- Know how to adapt materials for & - Are not comfortable with adapting \\
- online format & materials for online format \\
- Choose content and activities carefully & - Have subject-matter expertise but fall \\
- Constantly monitor, tweak, and & \\
\hline
\end{tabular}

\section{Discussion}

This study was based on interviews with online instructors who had won one of three online education awards from professional organizations (AECT, OLC, USDLA). Their insights provide rich data that can contribute to our understanding of excellence in online course design and how expert online instructors are different from novice online instructors. 


\section{Award-Winning Course Design}

Online course design elements valued by students have been documented in the literature and in quality standards (e.g., Quality Matters). Course announcements and reminders, course information documents (e.g., syllabus, schedules, outlines, grading procedures, and policies), and clarity on assignments are ranked as the top three course design elements for adult learners (Ausburn, 2004). Additionally, students value strong course organization, time-flexible feedback, the instructor's content ability and consistent support, and the relevance of both feedback and coursework (Fayer, 2014). While the literature focuses on these elements from the student perspective, the course design elements that emerged from this study represent faculty perspectives and add to what is known about excellence in online course design.

Authentic and relevant course materials that connect to practice. Award-winning instructors in our study emphasized the importance of using authentic online course materials (e.g., radio show recordings, courtroom videos), which help prepare students for future jobs. Authentic materials can impact student attitudes and alleviate student anxiety (Erbaggio, Gopalakrishnan, Hobbs, \& Liu, 2016). Digital resources, such as case studies and videos, help deliver relevant online course material, such as content that demonstrates how to do something, and can increase students' motivation to learn (Herrington \& Herrington, 2006).

Use of multimedia resources. Award-winning instructors in our study reported carefully selecting and using existing multimedia resources available online. They also created their own multimedia materials for their online courses by recording screencasts, lectures, podcasts, and interviews with experts or professionals in the field. Churchill (2017a) classified such types of digital resources as content resources. It was evident that award-winning instructors went beyond just using text-based materials to becoming curators and creators of content resources.

Researchers have examined the cognitive value of using multimedia in courses for several years (Moreno \& Mayer, 2000). More recently, new media, such as simulations, augmented reality, and virtual reality, are being included in online courses. Multimedia in online courses can motivate students and support student learning and engagement (Mandernach, 2009; Sherer \& Shea, 2011). Instructor-generated multimedia and instructor videos have been found to increase student engagement and social presence (Borup, West, \& Graham, 2012; Mandernach, 2009).

Student creation of digital content individually and collaboratively. Learning activities designed by award-winning instructors also focused on students' creation of digital content in the form of digital stories, websites, podcasts, or audiovisual presentations both individually and collaboratively. The participants considered such learning activities as important to engaging and involving students in their learning process, and they often modified tasks or activities (Espiritu \& Budhrani, 2019) based on formative feedback. Research has found that students also prefer the project-based application nature of activities and assignments, which help them create digital content (Heo, Lim, \& Kim, 2010).

Students' reflection on learning. John Dewey (1933) stated, "We do not learn from experience. We learn from reflecting on experience" (p. 78). Award-winning faculty in this study subscribed to this view, using a variety of student-reflection activities, such as discussion posts, student-created presentations, podcasts, and blogs. They also required reflection on quizzes, final exams, and self-assessment of students' interactions with peers. Participants believed this reflection helped students identify the progress they made in their learning and promoted engagement in the learning process. Herrington and Oliver (2002) described reflection as both an 
individually mediated and socially mediated process that can be fully integrated into online courses and provide opportunities for the student to reflect as they complete various course activities. Online reflection strategies, such as individual journaling, online discussions, and creating mind maps, have previously been recommended by Martin and Ertzberger (2015).

Purpose of activities, assessments, and technology used in the online course. The fifth element that award-winning faculty found important to their online course design was their explanation of the purpose of activities, assessments, and technology used in the online courses. Quality Matters (2019) includes quality standards about the alignment between objectives, materials, activities, technologies, and assessments in online courses. Such explicit alignment assists online students in seeing the purpose of activities and assessments in relation to the objectives and instructional material in online courses. Participants in this study also referred to the importance of students seeing the "bigger picture," and the importance of using technologies that support the objectives, activities, and assessments in an online course. This finding reinforces prior research from the student point of view on clarity and transparency in course design (Fisher et al., 2016; Musselman et al., 2016; Ralston-Berg et al., 2015).

\section{Faculty Use of Data in Online Courses}

While the focus of our questions was the elements of award-winning courses, instructors in our study emphasized their use of data for continuous improvement as contributing to the awardwinning nature of their online courses. They also underlined the importance of faculty reflection on course offerings to excellent course design. Their statements corresponded to literature on midsemester surveys as a helpful feedback tool (Sozer, Zeybekoglu, \& Kaya, 2019) and the usefulness of such data for immediate and remedial action, unlike the end-of-semester data (Alderman, Towers, \& Bannah, 2012). Our results also correspond to Baran, Correia, and Thompson's (2017) research that exemplary online faculty formatively evaluated their online courses in order to make changes during the course. While continuous improvement is emphasized in quality standards (e.g., Quality Matters), our study emphasizes the importance of (a) instructors' use of different types of data for reflection and for ongoing assessment and refinement of courses to excellence in online course design and (b) institutional support that assists instructors in their use of such data.

\section{Expert Versus Novice Online Faculty}

"Experts are not just those who have the wealth of experience from their years teaching online" (Martin et al., 2019, p. 40) but have the "fluency of teaching and learning with technology, not just with technology, itself" (Jacobsen, Clifford, \& Friesen, 2002, p. 44). The award-winning instructors in our study characterized expert online faculty as instructors who (a) had adapted and were comfortable teaching in the online environment, (b) used a wide range of strategies, (c) were willing to learn, (d) used analytics and stayed engaged in the course, and (e) reflected on what works and knowing what works in online courses.

Faculty in our study believed that novice instructors' creation of online courses is restricted to including instructional materials in the LMS, whereas expert online faculty have learned to adapt or create materials and activities for the online learning environment. They emphasized the differences in online teaching compared to face-to-face teaching and that different strategies were needed to design and teach an online course. Several of their insights corresponded to Baran et al.'s (2017) description of exemplary faculty whose expertise went beyond content to various facets of the online course. Our participants asserted that expert online instructors use a variety of 
strategies to design and facilitate online courses and that no matter how experienced they are, expert online faculty are willing to learn new strategies and technologies for online course design and teaching. Their insights correspond to Outlaw and Rice's (2015) findings from interviews that it is important for online faculty to be open-minded and willing to try new tools and online teaching concepts. An important point made by our participants is that of expert online instructors not being restricted by technology but using it for their goals. The participants in our study modeled such use in their course design, and also in the ways in which they used data for decision-making, supporting the students, and making online course improvements.

\section{Limitations}

While the present study resulted in several interesting and relevant findings, this research is not without limitations. First, the participants had won online education awards from particular professional organizations (AECT, OLC, USDLA), and other professional organizations or awards were not included in this study. Of the 15 instructors contacted, though only eight participants ultimately participated in the research, all of these participants shared the status of an awardwinning online instructor and had deep experiences with online teaching and learning. This was a purposeful sample of participants and, thus, the participants were relatively homogeneous on the key criterion used for recruitment. Second, the participants received their awards in different years and from different professional associations selected for inclusion in the study. Consequently, the participants may not have been able to fully account for all aspects of the award-winning course designs since their responses were based on memory and personal accounts. Finally, we did not use all possible methods of rigor for qualitative research, such as triangulation (e.g., observing the award-winning courses or reviewing their course syllabi), peer debriefing (e.g., participants did not review coding and interpretations), or prolonged engagement (e.g., participants were interviewed in one session). Employing additional methods of rigor would have augmented the credibility and trustworthiness of our findings.

\section{Future Research}

Growing online course offerings and expectations of faculty to teach online have created a need for effective models and best practices, and further investigation of what constitutes excellence in online course design and teaching. This is particularly important as emerging technologies (e.g., augmented or virtual reality), motivational strategies (e.g., gamification), and additional opportunities (e.g., badges) are integrated into online course design. Future research on award-winning instructors could dig deeper into the learning design of how instructors conceptualize, design, and use specific course elements; this can be done through a content analysis of actual award-winning course shells or syllabi, or by focusing on more specific research questions related to digital resources, activities, supports, and evaluations. Additionally, future research might also account for the multiple stakeholders involved in online learning, including instructional designers, faculty, administrators, multimedia developers, and ultimately, the primary users of these courses - the students. Online course design and development is no longer done in isolation by faculty tinkering with an LMS. Many stakeholders are involved in the full life cycle of online learning. Although expectations for quality online courses have been defined in the past, our study contributes to the literature on award-winning online instructors and elements of course design that represent excellence. These findings should continue to spur dialogue in both the online learning research and practice community. 


\section{References}

Alderman, L., Towers, S., \& Bannah, S. (2012). Student feedback systems in higher education: A focused literature review and environmental scan. Quality in Higher Education, 18(3), 261280.

Association for Educational Communications and Technology Distance Learning Awards. (2018). Retrieved from https://mms.aect.org/members/project_content.php?content_id=446931\&org_id=AECT

Ausburn, L. J. (2004). Course design elements most valued by adult learners in blended online education environments: An American perspective. Educational Media International, 41(4), $327-337$.

Bailey, C. J. (2008). Best practices for online teaching: Perceptions of South Dakota award-winning online university faculty. University of South Dakota.

Bailey, C. J., \& Card, K. A. (2009). Effective pedagogical practices for online teaching: Perception of experienced instructors. The Internet and Higher Education, 12(3-4), 152-155.

Baldwin, S., Ching, Y. H., \& Hsu, Y. C. (2018). Online course design in higher education: A review of national and statewide evaluation instruments. TechTrends, 62(1), 46-57.

Baldwin, S. J., \& Trespalacios, J. (2017). Evaluation instruments and good practices in online education. Online Learning 21(2). doi:10.24059/olj.v21i2.913

Baran, E., \& Correia, A. P. (2014). A professional development framework for online teaching. TechTrends, 58(5), 95-101.

Baran, E., \& Correia, A. P. (2017). What motivates exemplary online teachers? A multiple-case study. Learning, Design, and Technology: An International Compendium of Theory, Research, Practice, and Policy, 1-17.

Baran, E., Correia, A. P., \& Thompson, A. (2013). Tracing successful online teaching in higher education: Voices of exemplary online teachers. Teachers College Record, 115(3), 1-41.

Bennett, S., Agostinho, S., \& Lockyer, L. (2015). Technology tools to support learning design: Implications derived from an investigation of university teachers' design practices. Computers \& Education, 81, 211-220.

Bennett, S., Lockyer, L., \& Agostinho, S. (2018). Towards sustainable technology-enhanced innovation in higher education: Advancing learning design by understanding and supporting teacher design practice. British Journal of Educational Technology, 49(6), 1014-1026. https://doi.org/10.1111/bjet.12683

Bishop, J. L., \& Verleger, M. A. (2013). The flipped classroom: A survey of the research. 30, 1-18.

Borup, J., West, R. E., \& Graham, C. R. (2012). Improving online social presence through asynchronous video. The Internet and Higher Education, 15(3), 195-203.

Brown, V. S., Lewis, D., \& Toussaint, M. (2018). Students' perceptions of quality across four course development modules. Online Learning, 22(2), 173-195. doi:10.24059/olj.v22i2.1213

Chen, H.-L., \& Wang, S. (2016). Turning passive watching to active learning: Engaging online learners through interactive video assessment tools. 39th Annual Convention of the Association for Educational Communications and Technology, 1, 15-20.

Churchill, D. (2017a). Using digital resources for learning in a learning activity. In Springer texts in education. Digital resources for learning (pp. 133-158). Singapore: Springer Nature Singapore Pte Ltd. 
Churchill, D. (2017b). Educational reforms, learning-centred education and digital resources for learning. In Springer texts in education. Digital resources for learning (pp. 1-17). Singapore: Springer Nature Singapore Pte Ltd.

Churchill, D., King, M., \& Fox, B. (2013). Learning design for science education in the 21st century. Zbornik Instituta Za Pedagoška Istrazivanja/Journal of the Institute of Educational Research, 45(2).

Correia, A.-P., \& Jaramillo, N. (2016). Strengthening learner participation in online courses: The role of digital content curation. 39th Annual Convention of the Association for Educational Communications and Technology, 1, 21-23.

Cundell, A., \& Sheepy, E. (2018). Student perceptions of the most effective and engaging online learning activities in a blended graduate seminar. Online Learning, 22(3), 87-102.

Dewey, J. (1933). How we think: A restatement of the relation of reflective thinking to the educative process. DC Heath.

Dunkin, M. J., \& Precians, R. P. (1992). Award-winning university teachers' concepts of teaching. Higher Education, 24(4), 483-502.

Edwards, M., Perry, B., \& Janzen, K. (2011). The making of an exemplary online educator. Distance Education, 32(1), 101-118.

Erbaggio, P., Gopalakrishnan, S., Hobbs, S., \& Liu, H. (2016). Enhancing student engagement through online authentic materials. IALLT Journal of Language Learning Technologies, $42(2)$.

Espiritu, J. L., \& Budhrani, K. (2019). Cultivating an elearning culture. Scientia Pedagogica Experimentalis, 56(1), 3-32.

Fayer, L. (2014). A multi-case study of student perceptions of online course design elements and success. International Journal for the Scholarship of Teaching and Learning, 8(1), 13.

Fisher, K., Kouyoumdjian, C., Roy, B., Talavera-Bustillos, V., \& Willard, M. (2016). Building a culture of transparency. Peer Review, 18(1/2), 8 .

Gay, G. H. (2016). An assessment of online instructor e-learning readiness before, during, and after course delivery. Journal of Computing in Higher Education, 28(2), 199-220.

Giannakos, M. N., Krogstie, J., \& Aalberg, T. (2016). Video-based learning ecosystem to support active learning: Application to an introductory computer science course. Smart Learning Environments, 3(1).

Hattie, J. (2012). Visible learning for teachers: Maximizing impact on learning. London: Routledge.

Herrington, A., \& Herrington, J. (2006). What is an authentic learning environment? In A. Herrington \& J. Herrington (Eds.), Authentic learning environments in higher education (pp. 1-13). Hershey: Information Science Publishing.

Herrington, J., \& Oliver, R. (2002). Designing for reflection in online courses. In HERDSA 2002 Quality Conversations, 7-10 July 2002, Perth, Western Australia (pp. 313-319).

Heo, H., Lim, K. Y., \& Kim, Y. (2010). Exploratory study on the patterns of online interaction and knowledge co-construction in project-based learning. Computers \& Education, 55(3), 13831392.

Hixon, E., Barczyk, C., Ralston-Berg, P., \& Buckenmeyer, J. (2016). The impact of previous online course experience on students' perceptions of quality. Online Learning, 20(1), 25-40. 
Kember, D., \& McNaught, C. (2007). Enhancing university teaching: Lessons from research into award-winning teachers. Routledge.

Koohang, A., Paliszkiewicz, J., Klein, D., \& Nord, J. H. (2016). The importance of active learning elements in the design of online courses. Online Journal of Applied Knowledge Management, $4(2), 17-28$.

Lewis, C. C., \& Abdul-Hamid, H. (2006). Implementing effective online teaching practices: Voices of exemplary faculty. Innovative Higher Education, 31(2), 83-98.

Mandernach, B. J. (2009). Effect of instructor-personalized multimedia in the online classroom. The International Review of Research in Open and Distributed Learning, 10(3).

Markauskaite, L., \& Goodyear, P. (2014). Tapping into the mental resources of teachers' working knowledge: Insights into the generative power of intuitive pedagogy. Learning, Culture and Social Interaction, 3(4), 237-251.

Martin, F., Budhrani, K., Kumar, S., \& Ritzhaupt, A. (2019). Award-winning faculty online teaching practices: Roles and competencies. Online Learning, 23(1), 184-205.

Martin, F., \& Ertzberger, J. (2016). Effects of reflection type in the here and now mobile learning environment. British Journal of Educational Technology, 47(5), 932-944

Martin, F., Ritzhaupt, A., Kumar, S., \& Budhrani, K. (2019). Award-winning faculty online teaching practices: Course design, assessment and evaluation, and facilitation. The Internet and Higher Education, 42, 34-43.

Masterman, E. (2013). The challenge of teachers' design practice. In H. Beetham \& R. Sharpe (Eds.), Rethinking pedagogy for a digital age: Designing for 21st century learning (2nd ed.). New York, NY: Routledge.

McGee, P., Windes, D., \& Torres, M. (2017). Experienced online instructors: Beliefs and preferred supports regarding online teaching. Journal of Computing in Higher Education, 29(2), 331352.

Mentzer, B., Black, E. L., \& Spohn, R. T. (2015). An analysis of supports for persistence for the military student population. Online Learning, 19(1), 31-47.

Merriam, S. B., \& Tisdell, E. J. (2016). Qualitative research [Kindle edition]. San Francisco, CA: Josey Bass.

Miller, M. V., \& CohenMiller, A. S. (2019). Open video repositories for college instruction: A guide to the social sciences. Online Learning Journal, 23(2), 40-66.

Moore, M. G. (1993). Theory of transactional distance. In D. Keegan (Ed.), Theoretical principles of distance education. New York: Routledge.

Moreno, R., \& Mayer, R. (2000). A learner-centered approach to multimedia explanations: Deriving instructional design principles from cognitive theory. Interactive Multimedia Journal of Computer Enhanced Learning, 2(2).

Morris, D. B., \& Usher, E. L. (2011). Developing teaching self-efficacy in research institutions: A study of award-winning professors. Contemporary Educational Psychology, 36(3), 232-245.

Musselman, J. G., Lock, C., Long, C., Loughran, S., \& Saclolo, M. P. (2016). Design and implementation: Transparency and problem-based learning at St. Edwards University. Peer Review, 18(1/2), 28-30. 
Nguyen, G. N. H., \& Bower, M. (2018). Novice teacher technology-enhanced learning design practices: The case of the silent pedagogy. British Journal of Educational Technology, 49(6), 1027-1043. https://doi.org/10.1111/bjet.12681

Online Learning Consortium. (2018). Retrieved from https://onlinelearningconsortium.org/about/olcawards/

Outlaw, V., \& Rice, M. (2015). Best practices: Implementing an online course development \& delivery model. Online Journal of Distance Learning Administration, 18(3), 1-10.

Patton, M. Q. (2002). Qualitative research and evaluation methods. Thousand Oaks, CA: Sage Publications Ltd.

Quality Matters. (2019). Specific review standards from the QM higher education rubric (6th ed.) Retrieved from https://www.qualitymatters.org/sites/default/files/PDFs/StandardsfromtheQMHigherEducatio nRubric.pdf

Ralston-Berg, P., Buckenmeyer, J., Barczyk, C., \& Hixon, E. (2015). Students' perceptions of online course quality: How do they measure up to the research? Internet Learning, 4(1), 3.

Ross, S. R. P-J., Volz, V., Lancaster, M. K., \& Divan, A. (2018). A generalizable framework for multi-scale auditing of digital learning provision in higher education. Online Learning, 22(2), 249-270. doi:10.24059/olj.v22i2.1229

Saldaña, J. (2015). The coding manual for qualitative researchers. Thousand Oaks, CA: Sage.

Seaman, J. E., Allen, I. E., \& Seaman, J. (2018). Grade increase: Tracking distance education in the United States. Babson Survey Research Group.

Sener, J. (2015, July 7). Updated e-learning definitions. Retrieved from https://onlinelearningconsortium.org/updated-e-learning-definitions-2/

Sharp, L. A., \& Hamil, M. (2018). Impact of a Web-based adaptive supplemental digital resource on student mathematics performance. Online Learning, 22(1), 81-92.

Sherer, P., \& Shea, T. (2011). Using online video to support student learning and engagement. College Teaching, 59(2), 56-59.

Simpson, O. (2018). Supporting students in online, open and distance learning. Routledge.

Sozer, E. M., Zeybekoglu, Z., \& Kaya, M. (2019). Using mid-semester course evaluation as a feedback tool for improving learning and teaching in higher education. Assessment \& Evaluation in Higher Education, 44(7), 1003-1016.

United States Distance Learning Association Awards. (2018). Retrieved from https://usdla.org/awards/

Varvel, V. E. (2007). Master online teacher competencies. Online Journal of Distance Learning Administration, 10(1), 1-41

Watson, S. L., Koehler, A. A., Ertmer, P., Kim, W., \& Rico, R. (2018). An expert instructor's use of social congruence, cognitive congruence, and expertise in an online case-based instructional design course. Interdisciplinary Journal of Problem-Based Learning, 12(1), 3. 


\section{Appendix}

\section{Award-winning faculty interview questionnaire DEMOGRAPHICS}

1. Describe your current job title/position.

2. Gender

3. Ethnicity

4. How long have you been teaching in higher education?

5. How long have you been teaching online?

6. What learning management systems have you used to design and teach online?

7. How would you describe your online class structure?

a. Fully online (80-100\% is offered online)

b. Hybrid/blended (less than $80 \%$ is offered online)

8. How would you describe the approach to your online course?
a. $100 \%$ asynchronous
b. $100 \%$ synchronous
c. Mostly asynchronous with some synchronous
d. Mostly synchronous with some asynchronous
e. Blend of both asynchronous and synchronous

\section{ROLES, RESPONSIBILITIES, TASKS}

9. What are the various roles instructors take on in online learning?

10. What do you feel are your responsibilities as an online instructor?

11. What would you describe as the common tasks you implement when designing and teaching an online course?

12. For each of the roles identified, what competencies do online instructors need to teach online?

\section{DESIGN, SUPPORT, ASSESSMENT, EVALUATION \& FACILITATION}

13. Please describe for us your award-winning online course.

14. How do you organize your online courses?

15. Could you describe to us how you design your course?

16. Do you seek any assistance from specialists (e.g., graphics designers, instructional designers, etc.)?

17. Could you describe to us how you teach your course (e.g., the day-to-day work)?

18. Could you describe to us how you assess your students (e.g., quizzes, discussions, etc.)?

19. How do you evaluate whether your course is meeting your intended outcomes?

\section{TECHNICAL COMPETENCIES, EXPERT/NOVICE INSTRUCTORS}

20. What technical competencies do online instructors need to teach online?

21. How do expert instructors differ from novice instructors who teach online?

22. What should novice online instructors do to acquire strong competencies to be successful in online learning? 